\title{
European Union's Fiscal Aids and Its Effects on Member and Non-Member Countries: Turkey Case
}

\author{
İsmail Cem AY*, Erdem TURGAN**
}

\begin{abstract}
Since its foundation in XX. century, EU has remarkably developed within time and has reached today's status. It has always been one of the basic aims of EU to develop several mechanisms in order to help financially to its members and to the countries which are not members too for their easy integration to the Union. The main target of EU financial aids is to generally ensure the sustainable development of economic activities of member countries in conformity with the accepted economic policies of EU and to increase the harmony between EU and non-member countries. Therefore this study is intended to explain the impact of European Union's fiscal aids on member or non-member countries.
\end{abstract}

Keywords: European Union, financial aid, integration, economy policy, monetary policy.

\section{Avrupa Birliği'nin Mali Yardımlarının Üye ve Üye Olmayan Ülkeler Üzerindeki Etkileri: Türkiye Örneği}

$\ddot{0} z$

Avrupa Birliği'nin kuruluşundan beri zaman içinde olağanüstü derecede gelişmiş ve bugünkü düzeyine ulaşmıştır. Üyelerine finansal yardımlar yaparak bazı mekanizmalarının gelişmelerini sağlamak ve üye olmayan ülkelerin entegrasyonunu kolaylaştırmak Avrupa Birliği'nin temel amaçlarından birisi olmuştur. Avrupa Birliği'nin finansal yardımlarının temel amacı genellikle; üye ülkelerin Avrupa Birliği'nin kabul edilen ekonomi politikaları ile uyumlu olarak sürdürülebilir kalkınma süreçlerini garanti almak ve Avrupa Birliği ile üye olmayan ülkeler arasındaki uyumun artmasını sağlamaktır. Bu yüzden bu çalışma ile Avrupa Birliği mali yardımlarının üye ve üye olmayan ülkeler üstündeki etkileri açıklanmaya çalışılmıştır.

Anahtar Kelimeler: Avrupa Birliği, mali yardım, entegrasyon, ekonomi politikası, para politikası.

${ }^{*}$ Yrd. Doç. Dr., İstanbul Gelişim Üniversitesi, E-posta: icay@gelisim.edu.tr

** Öğ. Gör. Dr., Marmara Üniversitesi, E-posta: eturgan@marmara.edu.tr 
Sayfa/Page | 162 İGÜSBD Cilt: 2 Sayl: 1 Nisan / April 2015

\section{Introduction}

Fiscal Aids between European Union and Turkey had been carried out by Financial Protocols accepted at Ankara Agreement which was signed on October 12. 1963 until 1/95 Numbered Decision of Partnership Council. Purpose of these signed financial protocols is to provide fast progress to Turkish Economy. For this purpose, four financial protocols had been signed, but three of them were applied, fourth one was not applied because of political reasons. After these protocols, fiscal relations have been carried out based on the projects which were credit/donation type. There are two important turning points between the fiscal relations of Turkey and European Union. These are the Helsinki Summit Meeting (1999) at which Turkey was accepted as a candidate country and acceptance of Customs Union.

This study comprises of three chapters. In the first chapter, the EU budget, as the source of financial aid, is described in detail. In this framework, the own resources mechanism that constitutes the revenue of the budget, expenditure of the budget and the financial perspectives are explained. In the second chapter, the EU financial aid to Turkey and the positive and negative effects of this aid process both for EU and Turkey. Finally in the third chapter, Turkey-EU relations, the financial aid of the EU and the new procedures to be brought in the following years within the pre-accession aid are explained.

\section{The EU Budget Structure for the Source of Financial Aid}

The 2013 EU budget focuses on economic growth and job creation, needing in Europe in these tough times. The EU budget may represent a mere $1 \%$ of the EU's wealth, the main aim of the EU is smart, sustainable and inclusive growth strategy for the Europe 2020. Table 1 shows general budget the revenues of the European Union for the financial year 2013. The share of the GNI-based resource is $73.4 \%$ in 2013 , the share of the customs duties and sugar levies are $14.1 \%$, the share of the VAR-based resource is $11.3 \%$ and finally the share of the other revenue is $1.2 \%$ in 2013.

\section{Table 1: General Budget The Revenues of the European Union for the financial year 2013}

\begin{tabular}{|c|c|c|c|c|}
\hline \multirow{2}{*}{ Type of revenue } & \multicolumn{2}{|c|}{2012 budget } & \multicolumn{2}{|c|}{2013 budget } \\
\hline & EUR million & $\%$ & EUR million & $\%$ \\
\hline Customs duties and sugar levies & 16824.20 & 12.4 & 18755.20 & 14.1 \\
\hline VAT-based resource & 14546.30 & 10.7 & 15029.95 & 11.3 \\
\hline GNI-based resource & 97284.22 & 71.7 & 97502.87 & 73.4 \\
\hline Other revenue & 7103.52 & 5.2 & 1548.97 & 1.2 \\
\hline TOTAL & 135758.24 & 100.0 & 132836.99 & 100.0 \\
\hline
\end{tabular}

Source: European Union, "General budget The figures of the European Union for the financial year 2013" European Union, 2013, p.23 
Table 2 shows general budget the figures of the European Union for the financial year 2013. The level of the sustainable growth is 70147 (million, €) in the 2013 budget. The level of preservation and management of natural resources are 70147 (million, $€$ ) in the 2013 budget. Other components are relatively small levels in the budget.

\section{Table 2: General budget The figures of the European Union for the financial year 2013 (€,Mln,,current)}

\begin{tabular}{|c|c|c|c|c|c|c|c|c|c|}
\hline & APPROPRIATIONS FOR COMMITMENTS & 2007 & 2008 & 2009 & 2010 & 2011 & 2012 & 2013 & $\begin{array}{c}\text { Total } \\
2007-13\end{array}$ \\
\hline 1 & SUSTAINABLE GROWTH & 53979 & 57653 & 61696 & 63555 & 63974 & 67614 & 70147 & 438618 \\
\hline la & Competitiveness for growth and employment & 8918 & 10386 & 13269 & 14167 & 12987 & 14853 & 15623 & 90203 \\
\hline 16 & Cohesion for growth and employment & 45061 & 47267 & 48427 & 49388 & 50987 & 52761 & 54524 & 348415 \\
\hline \multirow[t]{2}{*}{2} & $\begin{array}{l}\text { PRESERVATION AND MANAGEMENT } \\
\text { OF NATURAL RESOURCES }\end{array}$ & 55143 & 59193 & 56333 & 59955 & 59888 & 60810 & 61289 & 412611 \\
\hline & $\begin{array}{l}\text { of which: market-related expenditure ard } \\
\text { direct payments (1) }\end{array}$ & 45759 & 46217 & 46679 & 47146 & 47617 & 48093 & 48574 & 330085 \\
\hline 3 & $\begin{array}{l}\text { CITIZENSHIP, FREEDOM, SECURITY } \\
\text { AND JUSTICE }\end{array}$ & 1273 & 1362 & 1518 & 1693 & 1889 & 2105 & 2376 & 12216 \\
\hline $3 a$ & Freedom, searity and justice & 637 & 747 & 867 & 1025 & 1206 & 1406 & 1661 & 7549 \\
\hline 36 & Citizenship & 636 & 615 & 651 & 668 & 683 & 699 & 715 & 4667 \\
\hline 4 & EU AS A GLOBAL PLAYER & 6578 & 7002 & 7440 & 7893 & 8430 & 8997 & 9595 & 55935 \\
\hline 5 & ADMINISTRATION (2) & 7039 & 7380 & 7525 & 7882 & 8091 & 8523 & 9095 & 55535 \\
\hline \multirow[t]{7}{*}{6} & COMPENSATIONS & 445 & 207 & 210 & & & & & 862 \\
\hline & TOTAL COMMITMENT APPROPRIATIONS & 124457 & 132797 & 134722 & 140978 & 142272 & 148049 & 152502 & 975777 \\
\hline & as a percentage of $\mathrm{GNI}(3)$ & $1.02 \%$ & $1.08 \%$ & $1.16 \%$ & $1.18 \%$ & $1.15 \%$ & $1.13 \%$ & $1.15 \%$ & $1.12 \%$ \\
\hline & TOTAL PAYMENT APPROPRIATIONS & 122190 & 129681 & 120445 & 134289 & 133700 & 141360 & 143911 & 925576 \\
\hline & as a percentage of $\mathrm{GNI}\left({ }^{3}\right)$ & $1.00 \%$ & $1.05 \%$ & $1.04 \%$ & $1.12 \%$ & $1.08 \%$ & $1.08 \%$ & $1.08 \%$ & $1.06 \%$ \\
\hline & Margin available & $0.24 \%$ & $0.19 \%$ & $0.20 \%$ & $0.11 \%$ & $0.15 \%$ & $0.15 \%$ & $0.15 \%$ & $0.17 \%$ \\
\hline & Own resources ceiling as a percentage of GNI & $1.24 \%$ & $1.24 \%$ & $1.24 \%$ & $1.23 \%$ & $1.23 \%$ & $1.23 \%$ & $1.23 \%$ & $1.23 \%$ \\
\hline
\end{tabular}

Source: European Union, "General budget The figures of the European Union for the financial year 2013" European Union, 2013

(1) This amount is before taking account of modulation and other transfers to rural development.

(2) The expenditure on pensions included under the ceiling for this heading is calculated net of the staff contributions to the relevant scheme, within the limit of EUR 500 million at 2004 prices for the period 2007-13.

(3) The figures are based on the technical adjustment of the financial framework for 2013 in line with movements in GNI, adopted by the Commission on 20 April 2012 (COM (2012) 184).

An important instrument in the EU budget structure for the source of financial aid is the Instrument for Pre-accession Aid (IPA) by which the EU supports reforms in the 'enlargement countries' with financial and technical help. The IPA funds build up the capacities of the countries throughout the accession process, resulting in progressive, positive developments in the region. IPA funding will amount to some €11.5bn over 2007-13. The beneficiary countries are: Albania, Bosnia and Herzegovina, Croatia, the
Sayfa/Page | 163

İGÜSBD

Cilt: 2 Sayı: 1

Nisan /

April 2015 
Sayfa/Page | 164 İGÜSBD Cilt: 2 Sayı: 1 Nisan / April 2015

former Yugoslav Republic of Macedonia, Iceland, Kosovo, Montenegro, Serbia, and Turkey. Detailed allocations per country are available in the IPA Multiannual Indicative Financial Framework. IPA replaces the previous instruments for pre-accession: Phare, ISPA, SAPARD, the pre-accession instrument for Turkey, and the financial instrument for the Western Balkans, CARDS. Since 2007, the enlargement countries have received EU funding and support through this single channel. ${ }^{1}$

EU pre-accession funds make political and economic reform easier in the beneficiary countries and prepare them for the rights and obligations that come with EU membership. With the EU's help, citizens in the enlargement region can enjoy better opportunities and overall conditions. Their countries can develop the same standards we enjoy as citizens of the EU. The preaccession funds also help the EU reach its own objectives regarding a sustainable economic recovery, energy supply, transport, the environment and climate change, etc. This is a sound investment in the future. The allocation of EU pre-accession funds helps translate the political priorities of the enlargement strategy into concrete actions. Through IPA, the EU reinforces its guidance to the aspiring countries on the priorities necessary for aligning with EU standards and legislation. ${ }^{2}$

The EU Financial Aid to Turkey and the Positive and Negative Effects of This Aid Process Both for EU and Turkey

The financial cooperation is one of the most important pillars of Turkish-EU relations which started in 1959. The attainment of candidate status in 1999 and the membership negotiations commenced on 3 October 2005, started a new period in financial cooperation with EU. With the 20022006 period, financial support mainly for capacity building projects on the adaptation of the acquis started with the attainment of candidate status. On the new budget period -2007-2013- the scope of the financial support was extended to cover broader areas. The European Union started the implementation of Instrument for Pre-accession Aid (IPA) in order to ensure the proper management of all types of pre-accession funds provided to candidate and potential candidate countries. IPA, bringing together all mechanisms used during previous periods, aims at supporting the candidate countries in membership negotiations and to prepare countries for the better management of future structural funds. A new structure was created in Turkey- EU financial cooperation with the implementation of IPA mechanism providing funds under Transition Aid and Institutional Building, Cross Border Cooperation, Regional Development, Human Resources Development and

${ }^{1}$ European Commission, "Enlargement Instrument for Pre-accession aid (IPA) Overview" http://ec.europa.eu/enlargement/instruments/overview/index en.htm 2 EU funding priorities is as follows (European Commission, "Enlargement Instrument for Pre-accession aid(IPA) Overview" http://ec.europa.eu/enlargement/instruments Loverview/index en.htm 
Rural Development components. (Ministry of Development of TR, Economic and Social Cohesion Policy).

2007-2013 period opens a new chapter in the relations between European Union and Turkey in terms of EU funds. After the accession of Bulgaria and Romania in the EU, European Commission revised its financial support system for candidate countries. Thereby, as of 2007 programs for candidate countries such as PHARE, ISPA and SAPARD are abolished and IPA Program is put into force as a replacement. The main objective of IPA is to ensure the gradual alignment of candidate countries with EU policies and standards and to prepare these countries for post accession Structural Funds and Cohesion Funds in order to align with the Acquis Communautarie. As of 2007, the grant funds allocated to Turkey by the EU are provided through IPA. Within this framework, Cohesion Funds are allocated under the scope of Regional Development and Human Resources Development components. These funds are transferred to projects complying with the priorities defined in the Strategic Coherence Framework, prepared under the coordination of the Ministry of Development and Operational Programs to be implemented under this framework. IPA financial aid is brought together under five components (Ministry of Development of TR, Economic and Social Cohesion Policy):

1. Transition aid and institutional building

2. Cross border cooperation

3. Regional development

4. Human resources development

5. Rural Development

In accordance with the Multi Annual Indicative Financial Framework, 4,831 billion euros are estimated to be allocated to Turkey for the 2007-2013 period. The distribution of the resources by components and years is as follows:

Table 3: Component Based Financial Allocations For Turkey Under MIFF (Billion Euros)

\begin{tabular}{|l|l|l|l|l|l|l|l|}
\hline IPA Components & $\mathbf{2 0 0 7}$ & $\mathbf{2 0 0 8}$ & $\mathbf{2 0 0 9}$ & $\mathbf{2 0 1 0}$ & $\mathbf{2 0 1 1}$ & $\mathbf{2 0 1 2}$ & $\mathbf{2 0 1 3}$ \\
\hline $\begin{array}{l}\text { Transition Aid and } \\
\text { Institution Building }\end{array}$ & 256,7 & 256,1 & 239,6 & 217,8 & 231,3 & 227,5 & 246,3 \\
\hline $\begin{array}{l}\text { Cross Border } \\
\text { Cooperation }\end{array}$ & 2,097 & 2,875 & 3,049 & 3,090 & 5,132 & 2,175 & 2,218 \\
\hline Regional Development & 167,5 & 173,8 & 182,7 & 238,1 & 293,4 & 356,8 & 378 \\
\hline $\begin{array}{l}\text { Human Resources } \\
\text { Development }\end{array}$ & 50,2 & 52,9 & 55,6 & 63,4 & 77,6 & 83,9 & 96 \\
\hline Rural Development & 20,7 & 53 & 85,5 & 131,3 & 172,5 & 189,8 & 213 \\
\hline Total & 497,2 & 538,7 & 566,4 & 653,7 & 779,9 & 860,2 & 935,5 \\
\hline
\end{tabular}

Resource: European Commission, MIFF, 2012-2013.

Sayfa/Page | 165 İGÜSBD Cilt: 2 Sayı: 1 Nisan / April 2015 
Sayfa/Page | 166 İGÜSBD

Cilt: 2 Sayı: 1 Nisan / April 2015
Table 4: Pre-Accession Financial Aid Process for Turkey: 1999-2006 Period ${ }^{3}$

\begin{tabular}{|c|c|c|}
\hline RESPONSIBLE & ACTION & PHASES \\
\hline European Commission & Proposes & \multirow{4}{*}{$\begin{array}{l}\text { Phase 1: } \\
\text { Budgetary } \\
\text { Decision }\end{array}$} \\
\hline Council & $\begin{array}{l}\text { Decides or no-decides } \\
\text { (Adaption of Legislation) }\end{array}$ & \\
\hline European Parliament & Agrees with no modificitaions & \\
\hline Council & $\begin{array}{l}\text { Decides on annual budget } \\
\text { amount allocated per } \\
\text { canditate country }\end{array}$ & \\
\hline $\begin{array}{l}\text { EU Commission (DG } \\
\text { Enlargement) }\end{array}$ & $\begin{array}{l}\text { Assesses annually the priority } \\
\text { areas where progress is } \\
\text { needed in order to prepare } \\
\text { for accession }\end{array}$ & \\
\hline $\begin{array}{l}\text { EU Commission (DG } \\
\text { Enlargement) }\end{array}$ & $\begin{array}{l}\text { Progress report for candidate } \\
\text { country is evaluated }\end{array}$ & \\
\hline $\begin{array}{l}\text { EU Commission (DG } \\
\text { Enlargement) }\end{array}$ & $\begin{array}{l}\text { Accession partnership } \\
\text { document is prepared }\end{array}$ & \\
\hline $\begin{array}{l}\text { Secretary General for EU } \\
\text { Affairs (Turkey) }\end{array}$ & $\begin{array}{l}\text { Sets out the measures } \\
\text { through which Turkey will } \\
\text { make progress to meet and } \\
\text { assuma the obligations of } \\
\text { membership (Copenhagen } \\
\text { criteria) Outlines the projects } \\
\text { and programmes to meet } \\
\text { Accession Partnership } \\
\text { Document }\end{array}$ & $\begin{array}{l}\text { Phase 2: } \\
\text { Programming }\end{array}$ \\
\hline $\begin{array}{l}\text { Secretary General for EU } \\
\text { Affairs (Turkey) }\end{array}$ & $\begin{array}{l}\text { National Programme for the } \\
\text { adoption of the acquise } \\
\text { (NPAA) is prepared }\end{array}$ & \\
\hline Fund Beneficiaries & $\begin{array}{l}\text { Read national programme } \\
\text { and submit their Project ideas } \\
\text { to goverment institutions } \\
\text { (ministries) }\end{array}$ & \\
\hline Ministries (Turkey) & $\begin{array}{l}\text { Evaluates the Project ideas } \\
\text { and prepare Project fiches } \\
\text { submits them Secretary }\end{array}$ & \\
\hline
\end{tabular}

${ }^{3}$ Source: Büküm, Z. (2012). The impact of Pre-Accession Financial Aid Policy of the European Union on Turkish Universities, Marmara University. IEU, Unpub. PhD.

Thesis, p.77. 


\begin{tabular}{|c|c|c|c|}
\hline & General for EU Affairs & & \\
\hline $\begin{array}{l}\text { Secretary General for EU } \\
\text { Affairs (Turkey) }\end{array}$ & $\begin{array}{l}\text { Secreatary General for EU } \\
\text { Affairs evaluates technically } \\
\text { the logical framework of the } \\
\text { Project fiches and their } \\
\text { compatibility }\end{array}$ & & $\begin{array}{l}\text { Sayfa/Page | } 167 \\
\text { İGÜSBD }\end{array}$ \\
\hline $\begin{array}{l}\text { Financial Committee } \\
\text { (Turkey) }\end{array}$ & $\begin{array}{l}\text { Determines the annual } \\
\text { programme for priority } \\
\text { themes to be funded } \\
\text { according to the Project } \\
\text { fiches, sends it to national aid } \\
\text { controller. }\end{array}$ & & $\begin{array}{l}\text { Nisan / } \\
\text { April } 2015\end{array}$ \\
\hline $\begin{array}{l}\text { National Aid Controller } \\
\text { (Turkey) }\end{array}$ & $\begin{array}{l}\text { Sends annual program to } \\
\text { Committee }\end{array}$ & \multirow{3}{*}{$\begin{array}{l}\text { Phase 3: } \\
\text { Evaluation }\end{array}$} & \\
\hline European Commission & $\begin{array}{l}\text { European Commission } \\
\text { evaluates the program and } \\
\text { decision on Financial } \\
\text { Memorandum }\end{array}$ & & \\
\hline EU Delegation (Turkey) & $\begin{array}{l}\text { Sends the Financial } \\
\text { Memorandum to National Aid } \\
\text { Coordinator }\end{array}$ & & \\
\hline $\begin{array}{l}\text { National Aid Controller } \\
\text { (Turkey) }\end{array}$ & $\begin{array}{l}\text { Sends the approved projects } \\
\text { fiches to the goverment } \\
\text { institutions and the Financial } \\
\text { Committee and sends a } \\
\text { confirmation rates per } \\
\text { projects to EU Commission }\end{array}$ & \multirow[t]{2}{*}{$\begin{array}{l}\text { Phase 4: } \\
\text { Financial } \\
\text { Agreement }\end{array}$} & \\
\hline $\begin{array}{l}\text { National Aid Controller } \\
\text { and European } \\
\text { Commission }\end{array}$ & $\begin{array}{l}\text { Financial Memorandum is } \\
\text { signed }\end{array}$ & & \\
\hline $\begin{array}{l}\text { National Authorisation } \\
\text { Officer (Turkey) }\end{array}$ & $\begin{array}{l}\text { Heads the financial } \\
\text { management process, } \\
\text { Requests the funds from the } \\
\text { Commission, direct them to } \\
\text { the National Fund and CFCU, } \\
\text { reports to the EU Commission }\end{array}$ & & \\
\hline CFCU (Turkey) & $\begin{array}{l}\text { Responsible for overall } \\
\text { budgeting, tendering, } \\
\text { contracting, payments, } \\
\text { accounting and financial } \\
\text { reporting aspects of all } \\
\text { procurement and opens }\end{array}$ & $\begin{array}{l}\text { Phase 4: } \\
\text { Implementation }\end{array}$ & \\
\hline
\end{tabular}




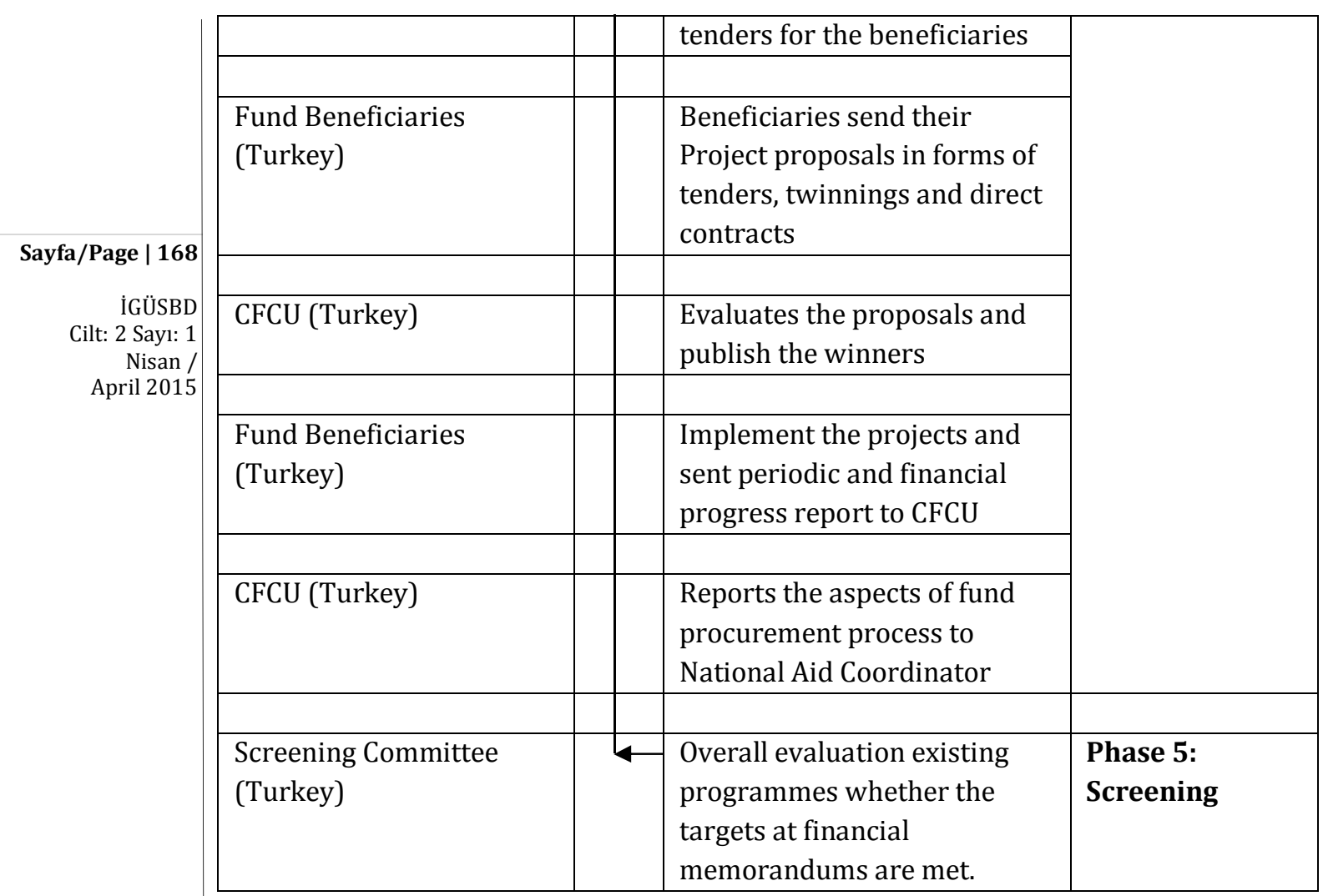


Table 5 : The Amount of Financial Aid of EU to Turkev (1964-2010)

\begin{tabular}{|c|c|c|c|c|c|c|c|c|}
\hline \multicolumn{3}{|c|}{ 1964-1996 } & \multicolumn{3}{|c|}{ 1996-1999 } & \multicolumn{3}{|c|}{$1999-2010$} \\
\hline $\begin{array}{l}\text { Fund Type/Program } \\
\text { Name }\end{array}$ & Period & Amount(ECU) & $\begin{array}{l}\text { Fund Type/Program } \\
\text { Name }\end{array}$ & Period & Amount (EURO) & Fund Type/Program Name & Period & Amount(EURO) \\
\hline CREDITS & $1964-1996$ & 1.266 .436 .000 & CREDITS & 1996-1999 & 217.000 .000 & CREDITS & $2000-2007$ & 1.850 .000 .000 \\
\hline I. Financial Protocole & $1964-1969$ & 175.000 .000 & EURO-MED-I & $1995-2000$ & 205.000 .000 & EUROMED & $2000-2003$ & 870.000 .000 \\
\hline 2. Financial Protocole & 1971-1977 & 219.936 .000 & Venture Capital & 1999 & 12.000 .000 & Special Action Plan & $2002-2003$ & 230.000 .000 \\
\hline Additional Protocole & $1971-1977$ & 47.000 .000 & GRANTS & & 425.400 .000 & Pre-aceossion Faeility & 2002 & 150.000 .000 \\
\hline 3. Financial Protocole & 1979-1982 & 310.000 .000 & $\begin{array}{l}\text { Grant Under Various } \\
\text { Programs }\end{array}$ & 1992-1999 & 14.000 .000 & TERRA-I & $2000-2003$ & 450.000 .000 \\
\hline 4. Financial Protocole & 1982-1986 & 0 & $\begin{array}{l}\text { Earthquake Emergency } \\
\text { Assistance }\end{array}$ & 1999 & 30.000 .000 & TERRA-II & 2000 & 150.000 .000 \\
\hline $\begin{array}{l}\text { Renewed Mediterranean } \\
\text { Policy Program }\end{array}$ & 1992-1996 & 339.500 .000 & Earthquake Rehabilitation & 1999 & 1.000 .000 & GRANTS & & 2.618 .537 .883 \\
\hline Gulf War Credits & 1991 & 175.000 .000 & Eathquake Relief (ECHO) & 1999 & 4.000 .000 & MEDA (B-7 4100) & $2000-2001$ & 343.058 .000 \\
\hline GRANTS & & 78.000 .000 & MEDA-1 & 1997-1999 & 376.400 .000 & $\begin{array}{l}\text { European Strategy for Social and Economic } \\
\text { Development (B-7 4036) }\end{array}$ & 2001 & 47.000 .000 \\
\hline Special Cooperation Fund & $1982-1986$ & 75.000 .000 & & & & $\begin{array}{l}\text { Marmara Earthquake Rehabilitation } \\
\text { Program }\end{array}$ & 2000 & 20.000 .000 \\
\hline \multirow[t]{10}{*}{\begin{tabular}{|l|} 
Administrative \\
Cooperation Fund \\
\end{tabular}} & 1993-1995 & 3.000 .000 & & & & $\begin{array}{l}\text { European Strategy for Strengthening The } \\
\text { Customs Union (B-7 4035) }\end{array}$ & 2000 & 13.000 .000 \\
\hline & & & & & & $\begin{array}{l}\text { Pre-accession Assistance (Including } \\
\text { Participating Community Programs) }\end{array}$ & 2002 & 126.000 .000 \\
\hline & & & & & & \begin{tabular}{|l} 
Pre-accession Assistance (Including \\
Participating Community Programs)
\end{tabular} & 2003 & 144.000 .000 \\
\hline & & & & & & $\begin{array}{l}\text { Pre-accession Assistance (nncluding } \\
\text { Participating Community Programs) }\end{array}$ & 2004 & 235.600 .000 \\
\hline & & & & & & $\begin{array}{l}\text { Pre-accession Assistance (Including } \\
\text { Participating Community Programs) }\end{array}$ & 2005 & 300.000 .000 \\
\hline & & & & & & $\begin{array}{l}\text { Pre-accession Assistance (Including } \\
\text { Participating Community Programs) }\end{array}$ & 2006 & 450.000 .000 \\
\hline & & & & & & $\begin{array}{l}\text { Pre-accession Assistance (IPA)(Including } \\
\text { Participating Community Programs) }\end{array}$ & 2007 & 261.393 .950 \\
\hline & & & & & & $\begin{array}{l}\text { Pre-accession Assistance (IPA)(Including } \\
\text { Participating Community Programs) }\end{array}$ & 2008 & 256.125 .297 \\
\hline & & & & & & $\begin{array}{l}\text { Pre-accession Assistance (IPA)(Including } \\
\text { Participating Community Programs) }\end{array}$ & 2009 & 204.550 .810 \\
\hline & & & & & & $\begin{array}{l}\text { Pre-accession Assistance (IPA)(Including } \\
\text { Participating Community Programs) }\end{array}$ & 2010 & 217.809 .826 \\
\hline TOTAL 1 & & 1.344 .436 .000 & TOTAL 2 & & 642.400 .000 & TOT AL 3 & & 4.468 .537 .883 \\
\hline \multicolumn{4}{|c|}{ TOTAL $(1+2+3)$} & \multicolumn{5}{|c|}{$\epsilon$ 6.455.373.883 } \\
\hline
\end{tabular}

Sayfa/Page | 169

İGÜSBD

Cilt: 2 Sayı: 1

Nisan /

April 2015

Source: Büküm, Z. (2012). The impact of Pre-Accession Financial Aid Policy of the European Union on Turkish Universities, Marmara University. IEU, Unpub. PhD. 
Sayfa/Page | 170 İGÜSBD Cilt: 2 Sayl: 1 Nisan / April 2015

Turkey-EU Relations, the Financial Aid of the EU and the New Procedures to be Brought in the Following Years within the PreAccession Aid

The main goal of the EU financial aid to Turkey, is to enhance the institutional capacity, the quality of legislation, the quality of implementation of the legislation so as to make it possible to integrate easily to common policies (like social policies, development, rural policies) when Turkey becomes a full member of EU. After the full membership negotiations began in October 2005, there has been a substantial increase in TR-EU financial aid budget. Later on, with the 2007-2013 budget period, the mechanisms of financial aid of EU to candidate and potential candidate countries are consolidated into a single instrument which is called Instrument for PreAccession Aid (IPA). ${ }^{1}$

The financial aid of the EU and the new procedures to be brought in the following years within the pre-accession aid are Instrument for Pre-accession aid (IPA). IPA funding to candidate and potential candidate countries is planned in the following stages (European Commission Enlargement Instrument for Pre-accession aid (IPA) How does it work?)2:

Multi-annual Indicative Financial Framework (MIFF): This document allocates IPA funds by country and by components, based on objective and transparent criteria, including needs assessment. The MIFF is reviewed every year and published each autumn together with the progress reports and the enlargement strategy, which sets out the overall strategic framework for the pre-accession process, including the IPA. The MIFF is the link between the strategic political framework and the budgetary process. The table here shows a summary of allocation of funds by country in million (€).

Multi-annual Indicative Planning Documents (MIPDs): Based on the MIFF allocations (and on the priorities identified within the strategic political framework and set out in the European Partnerships and Accession Partnerships for each country), the Commission, working closely with the beneficiary countries, establishes multi-annual indicative planning documents (MIPD) for each country and for the multi-beneficiary actions. Following a careful assessment of the country(ies) specific needs and challenges, the MIPDs indicate the major areas of intervention, highlighting a limited number

${ }^{1}$ KOSGEB, Instrument for Pre-Accession Aid (IPA), http://kosgeb.gov.tr/Pages/UI/ Baskanligimiz.aspx?ref=119

${ }^{2}$ http://ec.europa.eu/enlargement/instruments/how-does-it-work/index en.htm 
of priorities which will receive IPA funding. The MIPDs are established for a three-year rolling period, with annual reviews.

National authorities are very closely involved in the preparation of the MIPDs in order to ensure full "ownership" of the process. Civil society representatives are consulted during the preparation of the MIPDs. EU countries and other bilateral and multilateral donors are also consulted to ensure coordination, coherence and complementarity between the respective aid programmes.

Detailed annual/multi-annual programmes: The priorities outlined in the MIPDs are translated into detailed measures, operations and projects. These are all then included in programmes, which can be annual or multiannual. Annual / multi-annual programmes are financing decisions adopted by the European Commission specifying fields of intervention, objectives pursued, expected results, management procedures, and the total amount of financing planned.

IPA programmes: Annual / multi-annual programmes are financing decisions adopted by the European Commission specifying: fields of intervention, objectives pursued, expected results, management procedures, total amount of financing planned.

Programmes come under 5 different subject headings ("components"), and are managed by the following Commission departments:

- $\quad$ Component I - Transition aid \& institution building - DG Enlargement.

- $\quad$ Component II - Cross-border cooperation - DG Enlargement (for programmes between beneficiary countries) and DG for Regional and Urban Policy (programmes with EU countries).

- Component III - Regional development - DG for Regional and Urban Policy.

- Component IV - Human resources development - DG Employment, Social Affairs \& Inclusion

- Component V - Rural development - DG Agriculture and Rural Development.

Implementation: IPA-funded tasks are implemented and managed in various ways:

- Centralised - the Commission manages components like Transition aid \& institution building, and Cross-border cooperation 
Sayfa/Page | 172 İGÜSBD
- until the relevant national authorities are accredited to manage the funds.

- Decentralised - the beneficiary countries manage components like Regional development, Human resources development and rural development, once the Commission has confirmed they are able to implement aid in accordance with the Financial Regulation and are meeting the required conditions. In other words the Commission delegates the management of certain measures to the beneficiary country, while still retaining overall final responsibility for the general budget execution.

One of the main objectives of IPA is to transfer know-how and experience to beneficiary countries, by encouraging them to take ownership and responsibility for implementation. Decentralised management is therefore expected to become the norm. For this to be achieved, individual recipient countries should:

- Have specific strategies, action plans and timetables in place for moving towards decentralised management

- Prepare their national authorities to take on the increased responsibilities.

- Shared management - Implementation tasks are delegated to EU member states in accordance with the Financial Regulation (only for cross-border cooperation programmes with EU countries).

- Joint management - Implementation tasks of, for example, some multi-beneficiary actions, are delegated to an international organisation such as the United Nations or the World Bank.

Monitoring and evaluation of aid: The European Commission supervises the implementation of pre-accession programmes through its departments (DG Enlargement; DG Regional and Urban Policy; DG Employment, Social Affairs \& Inclusion; DG Agriculture and Rural Development) and through the EU Delegations in the beneficiary countries. Joint monitoring committees (Commission and beneficiary countries) monitor the implementation of financial aid programmes. Monitoring and evaluation reports are produced and corrective actions agreed upon when necessary. Further monitoring takes place at sector and project level. DG Enlargement carries out evaluations of financial aid which provide inputs for improving the quality, effectiveness and consistency of how EU funds are used and how programmes are implemented. The findings, results and recommendations of the evaluations are translated into better project design and implementation, and also resource allocation. 
Reporting: The Commission publishes an annual report on preaccession aid for the European Parliament, the EU Council and the European Economic and Social Committee. The report covers the previous budget year (i.e. the 2012 report covers 2011 and so on). (European Commission Enlargement Instrument for Pre-accession aid (IPA) How does it work?) ${ }^{3}$

\section{Conclusion}

Main aim of this study is to investigate European Union's fiscal aids and its affects to member and non-member countries especially for Turkey. This study comprises of three chapters. In the first chapter, the EU budget, as the source of financial aid, is described in detail. In this framework, the own resources mechanism that constitutes the revenue of the budget, expenditure of the budget and the financial perspectives are explained. In the second chapter, the EU financial aid to Turkey and the positive and negative effects of this aid process both for EU and Turkey. Finally in the third chapter, TurkeyEU relations, the financial aid of the EU and the new procedures to be brought in the following years within the pre-accession aid are explained.

In this study that searches the financial aid offered by European Union, there are two main results. The first is that, generally the determinative of the amount of the European Union's financial aid and diversity is the political relations between European Union and the other associated contries. The second main result is the change in the perspective in Turkey, especially in the state agencies and the ruling bureacracy of the European financial aid in time. It is seen that before financial protocols and nomination process, the EU financial aid was considered as such an aid that fills in the gaps in the economy while it was considered after the nomination period with the acceleration of the status agencies in union legislation harmonization that these financial aids were used more efficiently and widely, not only in the economy but also for the harmonization of the institutions and structures in Turkey to the European Union.

On the other hand since the Ankara Agreement in 1964 the process having passed so far, even if it has been observed an increase in the financial amount that has been provided to Turkey but it does not mean that all these financial aids predicted have been used or will be used. Especially, the national development plans, regional programs and projects need to be prepared and applied suitable for the EU perspective and norms. It shows that after the nomination period, the EU financial aid has rapidly increased both in the corporate and in the regional area and these financial aids increased more with the negotiation process and rather than the question," from whom

${ }^{3}$ http://ec.europa.eu/enlargement/instruments/how-does-work/index en.htm

Sayfa/Page | 173

İGÜSBD

Cilt: 2 Sayı: 1

Nisan /

April 2015 
Sayfa/Page | 174 İGÜSBD Cilt: 2 Sayı: 1 Nisan / April 2015

(local/regional actors \& central government) or how (Project-based \& grants) has the aids been taken from the EU?", as it has been during the period passed till the negotiation the continuity and the amount of the financial aids determine the political relations between Turkey and EU during the negotiation process and unless the relationship fail, EU will reveal to expand its financial aid. As a result, it can be said that if the financial aid made is used in the right areas by the countries, the EU's aims will be fulfilled and will be an essential financial source for the countries.

\section{REFERENCES}

BAŞBAKANLIK DIŞ TİCARET MÜSTEŞARLIĞI, Avrupa Birliği ve Türkiye, 5.Baskı, Doğuşum Matbaacılık, Ankara, Kasım 2002.

BİLİCİ, Nurettin, Türkiye-Avrupa Birliği İlişkileri (Genel Bilgiler, İktisadi ve Mali Konular, Vergilendirme) Seçkin Yayınları, Ankara, 2004.

BÜKÜM, Z. The impact of Pre-Accession Financial Aid Policy of the European Union on Turkish Universities, Marmara University, 2012 (IEU, Unpub. PhD. Thesis).

EUROPEAN COMMISSION, "Enlargement Instrument for Pre-accession aid (IPA) How does it work?" http://ec.europa.eu/enlargement/ instruments/how-does-work/index en.htm

EUROPEAN COMMISSION, "Enlargement Instrument for Pre-accession aid (IPA) Overview" http://ec.europa.eu/enlargement/ instruments/over view/index en.htm

EUROPEAN COMMISSION, MIFF, 2012-2013.

EUROPEAN UNION, "General budget The figures of the European Union for the financial year 2013" European Union, 2013.

GÖSTERİCI, Hüseyin ve Burhan ORMANOĞLU, "Avrupa Birliği "IPA" Mali Yardım Sistemi/2007-2013 Dönemi Uygulaması”, Bütçe Dünyası Dergisi, Cilt 2, Sayı 25, 2007.

KOSGEB, Instrument for Pre-Accession Aid(IPA), http://kosgeb.gov. tr/Pages /UI/Baskanligimiz.aspx?ref=119

MALLIK, Girijasankar, "Foreign Aid and Economic Growth: A Cointegration Analysis of the Six Poorest African Countries", Economic Analysis \& Policy, Vol. 38, No. 2, September, 2008, s.251-260.

PAPANEK, Gustav, "Aid, Foreign Private Investment, Savings, and Growth In Less Developed Countries", The Journal of Political Economy, Vol.81, No.1, 1973, pp.120-130,

SAKAL, Mustafa ve Metin AY, Avrupa Birliği'nde Yapısal Fonlar ve Mali Yardımlar, Avrupa Birliği Üzerine Yayınlar, İstanbul 2004. 
SÜNGÜ, Serdar, Avrupa Birliği Mali Yardımlarının Topluluğa Yeni Katılmış ve Katılacak Olan Ülkelerle Türkiye Açısından Değerlendirilmesi, Sayıştay Dergisi, Sayı: 54, 2004, ss. 54-111.

\section{Özet}

Bu çalışma ile Avrupa Birliği'nin mali yardımlarının üye ve üye olmayan ülkeler üzerindeki etkileri açıklanmaya çalışılmıștır. Sözkonusu yardımların bütçe içindeki yeri ve finansman kaynakları belirtilmiştir. Ancak bununla beraber mali yardımların başlangıç ve bitiş süreleri ile aynı dönemlerdeki siyasi gelişmeler arasındaki paralellikler de dikkat çekmiştir. Birliğin ülkelere sürdürülebilir kalkınmalarını garanti altına almak ve aday ülkelerin Avrupa Birliği politikalarına uyumlu hale gelmelerini daha da kolaylaştırmak amacıyla sunduğu bu mali yardımların hangi şartlar altında ve hangi koşullara bağlı olarak kullandırılacağı açıklanmıştır. Avrupa Birliği'nin sunduğu mali y ardımları inceleyen bu çalışmada iki temel sonuç bulunmaktadır. Bunlardan ilki, Avrupa Birliği mali yardımlarının miktarının ve çeşitliliğinin belirleyicisinin çoğu zaman Avrupa Birliği ile sözkonusu ülkeler arasındaki siyasi ilişkiler olduğudur. Örneğin Türkiye ile askeri darbe sebebiyle ilişkilerin donduğu 19801986 döneminde hiç mali yardım alamayan Türkiye, aday ülke statüsünün onaylandığı 1999'dan sonraki 6 yıl içinde iliş̧kilerin başladığı ilk 36 yılda alamadığı mali yardımı alabilmiştir. Íkinci temel sonuç ise Türkiye'deki özellikle devlet kurumlarının ve egemen bürokrasinin Avrupa Birliği mali yardımlarına olan bakış açısında zaman içinde meydana gelen değişimlerdir. Mali protokoller ve adaylık öncesi dönemde $A B$ mali yardımlarına sadece ekonomide açıkları kapatmak için gelen yardımlar olarak bakılırken, adaylık sonrası dönemde devlet kurumlarının Birlik mevzuatına uyum çalışmalarının hızlanmasıyla beraber bu mali yardımların sadece ekonomide değil, Türkiye'deki kurum ve yapıların Avrupa Birliği'ne uyumunu sağlayabilmek için daha etkin ve yaygın bir şekilde kullanılmakta olduğunu görülmektedir. Türkiye'nin bu dönemdeki önemli bir avantajı da aday ülke durumunda olan sadece üç ülkenin yani Hırvatistan ve Türkiye ve Makedonya'nın katılım öncesi mali yardımlardan yararlanacak olmasıdır. Bu sayede bu üç ülkeye ayrılmış olan toplam bütçeden Türkiye'nin Ankara Anlaşması'ndan müzakerelere kadar aldığı toplam mali yardımdan fazlasını 2007 - 2013 yılları arasında aldığı görülmektedir.

Diğer taraftan 1964 tarihli Ankara Anlaşmasından bugüne kadar geçen 40 yıllık bir sürede Türkiye'ye sağlanan mali yardım miktarının, Toplulukla ilişkileri 1990'lı yıllarda başlamış ve 10 tanesi 2004 Mayısında üye olmuş ülkelere sağlanan mali yardım miktarının oldukça gerisinde kaldığı görülmektedir. Türkiye'ye 40 yılda sağlanan hibe nitelikli toplam yardım miktarı
Sayfa/Page | 175

İGÜSBD

Cilt: 2 Sayı: 1

Nisan /

April 2015 
Sayfa/Page | 176 İGÜSBD Cilt: 2 Sayı: 1 Nisan / April 2015
1,456 milyar Euro'dur. Buna karşıllık, 1990 - 2006 dönemi için PHARE, ISPA ve SAPARD Programlarından, Merkezi ve Doğu Avrupa ülkelerine ayrılan mali yardım miktarının yıllık ortalaması 1.8 milyar Euro'yu geçmektedir. Birliğe üye olan ülkelere Topluluk Bütçesinden sağlanacak yardımlar da göz önüne alındiğında 1990 - 2006 dönemi için, Türkiye hariç genişlemeye ayrılan ortalama yıllık mali yardım miktarı 4.174 milyar Euro'dur.

Her ne kadar mali yardımların miktarında bir artış gözlenmekte ise de bu öngörülen bütün mali yardımların kullanıldı̆̆ı ya da kullanılacağı anlamına gelmemektedir. Özellikle ulusal kalkınma planlarının, bölgesel programların ve projelerin $A B$ perspektifi ve normlarina uygun hazırlanmasi ve uygulanmasi gerekmektedir. Çünkü mali protokoller ve adaylık öncesi dönemde kullanılan mali yardımların çok az bir bölümü proje karşılığında kullandırılmaktaydı. Ancak adaylık sonrası dönemde Türkiye, mali yardımlarından özellikle de proje bazlı yardımlardan büyük ölçüde yararlanma imkânına sahip olmuştur. Bu durum ise Türkiye'nin hazırlıksız yakalandı̆̆ı bir durumdur. Örneğin Avrupa Birliği Türkiye Temsilciliği verilerine göre 2005 yılında proje bazlı verilen 250 milyon Euro'luk paketin sadece 130 milyon Euro'luk kısmı projelendirilebilmiştir. $A B$ tarafindan bu durum tespit edilmiş ve bu mali/bölgesel yardımların Kalkınma Ajansları eliyle yerel bazda projelendirilmesi istenmiştir. Bu amaçla 25 Temmuz 2009'da çıkarılan Bakanlar Kurulu Kararı ile (2009/15236), ülkemizde 26 adet Kalkınma Ajansı'nın tamamı kurulmuştur. AB mali yardımlarının adaylık sonrası dönemde gerek kurumsal alanda gerekse de bölgesel alanda hızlı bir artış göstermekte olduğunu, müzakere süreci ile beraber bu mali yardımların daha da arttığını göstermekte ve AB'den alınan mali yardımların kimler tarafindan kullanıldığı (yerel/bölgesel aktörler\&merkezi hükümet) ya da nasıl (proje bazlı \& hibe) kullandırıldığından çok, bu mali yardımların sürekliliğinin ve miktarının müzakerelere kadar geçen dönemde olduğu gibi, müzakere süreci sırasında da Türkiye'nin AB ile olan siyasi ilişkilerine bağlı olduğunu belirlemekte ve müzakere sürecinde siyasi ilişkilerin bozulmaması halinde $A B$ mali yardımların daha da artacağını ortaya koymaktadır. Çalışmanın sonucunda ise yapılan mali yardımların ülkeler tarafindan doğru alanlarda kullanıldığında Avrupa Birliği'nin amaçlarının gerçekleștiği ve ülkeler için de önemli bir finansman kaynağı olduğu ortaya konmuştur. 